\title{
Shaping Facebook and Twitter Public Spheres: The Case of Swiss Franc Mortgage Holders in Poland
}

\author{
Kamil Filipek
}

ORCID: 0000-0003-0466-9388

Maria Curie-Sklodowska University in Lublin*

Andrzej Cwynar

ORCID: 0000-0003-2702-0397

University of Economics and Innovation in Lublin ${ }^{* *}$

Wiktor Cwynar

ORCID: 0000-0001-6890-5189

University of Economics and Innovation in Lublin ${ }^{* * *}$

\section{Jarosław Szkoła}

ORCID: 0000-0002-6043-3313

University of Rzeszów ${ }^{* * * *}$

\begin{abstract}
The article focuses on the online communication on Polish Facebook and Twitter around issues related to mortgage loans in Swiss francs. Based on 20k posts retrieved from both Facebook and Twitter, we found the most active actors and the most common topics appearing on those micro-public spheres. It was revealed that actors with institutional affiliation and those who are not affiliated discuss different problems and share dissimilar content related to Swiss franc debts. It was also found that certain categories of actors may influence online discussions on both social networking sites by promoting specific content in order to pursue their institutional interests. Finally, the diversity of topics and problems discussed by the two categories of actors identified on Facebook and Twitter suggest that Swiss franc mortgage holders are a good example of "connective action" with no clear identity or community traits that led to favourable judgment of the European Court of Justice.
\end{abstract}

Keywords: Facebook, Twitter, public sphere, topic-modelling.

\footnotetext{
*Institute of Sociology; kfilipek@umcs.pl

${ }^{\star *}$ Faculty of Social Sciences and Administration; andrzej.cwynar@wsei.lublin.pl

F** Faculty of Social Sciences and Administration; wiktor.cwynar@wsei.lublin.pl

${ }^{\star * * *}$ Faculty of Mathematics and Natural Sciences; jszkola@ur.edu.pl
} 
$\mathrm{G}$ ommunication on social media platforms such as Facebook and Twitter has become a popular research theme as people have turned to online communication tools to share their opinions, views, or emotions on diverse social issues, e.g. gay rights, gun control, or abortion. Optimists suggest that social media has become a new deliberative space (Habermas, 1962) for citizens, governments and companies to discuss and adjudicate (Benkler, 2004; Boyd, 2010) socially compelling problems. Accordingly, platforms such as Facebook or Twitter may serve as public spheres (counterpublics) coalesced around common concerns that may expose and enhance citizens' voices (Batorski \& Grzywińska, 2017; Fuchs, 2014; Lindgren \& Cocq, 2017). The Arab Spring, the Gezi Park, or the Black Lives Matter movement are examples of effective digital actions raised by citizens mobilized around scorching public issues. Scholars suggest that functionalities of Facebook, Twitter, or YouTube have the potential to equip users with tools that will improve circulation of information, exposure to cross-cutting news, public dialogue, voting, or grassroots mobilizations (Boulianne, 2015; Digrazia, Mckelvey, Bollen, \& Rojas, 2013; Lewis, 2015; Tang \& Lee, 2013; Vitak et al., 2011).

Simultaneously, there are numerous studies unveiling the negative impact of social media on public communication and contemporary democracy. Fuchs (2013) and Sunstein (2007) point to "fragmentation" of the public sphere as potentially negative effect that may diminish citizens' voices in digital space. Morozov (2009) warns that online activists are rather "slacktivists", a lazy form of activism that is focused on meaningless online activities such as clicking or sharing. Apparently "slacktivism" is disconnected from the democratic idea of citizens engaged in diverse public issues, actively controlling and influencing the actions of governments or politicians. In a similar vein, Mohammed (2012) claims that social media enable the spread of ignorance and breach of privacy. He proposed the term "fictional osmosis" to depict a viral spread of information through social media. As follows, An et al. (An, Quercia, \& Crowcroft, 2014) claim that social networking sites such as Facebook and Twitter encourage so-called partisan sharing. Partisan sharing has negative consequences as it may lead to "selective exposure" and a distorted sense of reality.

Despite the mentioned failures and limitations, social media has become a primary source of information for many users worldwide (We Are Social \& Hootsuite, 2017). According to PEW Research in 2016, 62\% of adults in the U.S. get news on social media (Pew Research Center, 2016). In Poland, social media is indicated as the second most important source of information for Internet users in 2017, just after a few major web portals (CBOS, 2017). Contrary to some prior studies, it is assumed here that "fragmented" but clear-cut "networked publics" (Boyd, 2010) that are formed around certain topics or events may help people to 
achieve a wide range of individual and community goals. Such event-related or interest-based communities focused on specific issues may be a good source of information and knowledge for people seeking expertise, advice, or support on social media. However, small networked publics may also become a subject for manipulation and propaganda sponsored by different categories of actors (Ferrara, 2015). This structural weakness of information (capitalist) media has been formerly discussed by Habermas (1991, p. 171) and more recently by Fuchs (2013, 2014), who focused on social media landscape.

Building on these arguments, this essay focuses on a networked public formed by Swiss franc borrowers - "Frankowicze", in Polish - who are active on Facebook and Twitter. Since 2009, Swiss franc borrowers in Poland have tried to persuade public authorities and commercial banks to introduce law helping them to convert Swiss franc mortgages into Polish zlotys. Although problems of "Frankowicze" are frequently discussed in newspapers and TV, to the best of our knowledge there are no studies explicitly focused on their activity on social media. Consequently, the following research questions are pursued: (i) What are the main topics discussed by users interested in "Frankowicze" issues? (ii) Do institutional actors influence the shape of social media discussions that are focused on Swiss franc borrowers? (iii) Do "Frankowicze" follow the logic of collective or rather connective action (Bennett \& Segerberg, 2012)?

\section{Swiss franc debts in Poland}

The first Swiss franc loans were granted in Poland in 2000. At that time, mortgages denominated in Polish zloty were very expensive - the annual interest rate was above $20 \%$ - and, as a result, Polish zloty mortgages did not constitute a significant share of banking sector's lending activities. Simultaneously, low interest rates in developed economies - including Switzerland — induced some banks to offer Poles foreign currency housing loans ( $\mathrm{fx}$ loans, hereafter). Polish households willingly and increasingly applied for such loans, not only because of low interest rates, but also as a result of progressive growth in the wealth of the average household and increased aspirations entailed by the growth. Additionally, the Swiss currency was systematically depreciating in relation to Polish zloty during the initial period of Swiss franc loans availability in Polish market. This lulled the vigilance of potential borrowers and, to a degree, the banking sector, and caused the belief that such a lending environment is sustainable.

At the same time, the banking sector in Poland developed significantly in the period 2000-2005. This led to increased competition, which was reflected in visibly more aggressive marketing campaigns of banks aimed at boosting demand for loans. Although the Polish Bank Association postulated banning granting foreign currency loans as far back as 2005, some banks were heavily determined to 
increase their client bases through Swiss franc loans, readily selected by Polish consumers. Continuously increasing demand coupled with a massive housing deficit resulted in a sharp increase in real estate prices, which doubled in the years 2005-2007. This raised concerns about a possible "price bubble" in the market for housing and entailed the issuance of "Recommendation S" by the Polish Banking Supervision Authority in March 2006 (a set of precautionary guidelines and regulations for banks that aimed at making foreign currency loans less available to consumers). This was only temporarily effective because the sale of Swiss franc mortgages achieved its peak in 2008: banks granted 162,000 of such loans (69\% of all newly granted loans) for the amount of PLN 56 billion (Centrum Grabskiego, 2016; Radio Poland, 2012).

In September of the same year (2008) Lehmann Brothers collapsed, instigating a global crisis - initially in the United States, and subsequently in Europe. Considering that the Swiss franc is deemed an extraordinarily safe investment that is preferred during crisis periods, demand for the currency quickly grew, substantially lifting its value in relation to other currencies, including the euro and Polish zloty. The appreciation of the Swiss franc, accompanied by a series of additional precautionary regulations introduced by the Polish Financial Supervision Authority (December 2008 - Recommendation S II; February 2010 - Recommendation T; January 2011 - Recommendation S III), resulted in the removal of foreign currency loans from banks' offers, starting in 2010. The appreciation of the Swiss currency was exacerbated in 2011 when financial problems of Greece and its potential bankruptcy, coupled with the threat of Grexit, emerged.

The stock market crash of 2008 coupled with the decline in housing prices (from now on referred to as the "Swiss franc problem") and the rising exchange rate of the Swiss franc to the Polish zloty caused material troubles for borrowers holding mortgages denominated in or indexed to Swiss currency. The levels of debt have gone up along with costs of monthly instalments, which have driven many debtors into serious socio-economic problems, including currency changeover difficulties, dispossession, consumer bankruptcy, or even suicide. Anxious Swiss franc borrowers in Poland have effectively organized themselves and built pressure on government and banks to pass a law allowing them to convert Swiss franc mortgages into zlotys with a favourable exchange rate. Curiously, statistics show that this segment of borrowers does not exhibit repayment problems greater than in other segments of mortgage debtors. Moreover, Swiss franc borrowers as a whole constitute a relatively small share of the total population of debtors in Poland (6\% according to the Bureau of Credit Information, 2017). Despite this fact, Swiss franc debtors grew strong not only in the media, but also in eyes of politicians searching for potential supporters. Swiss franc debts-related 
issues are good example of hot and polarising topic that reveals the impact of different actors pursuing their own interests. Not surprisingly, therefore, in recent political campaigns in Poland, candidates run with promises for those indebted in Swiss francs.

\section{Literature review and hypotheses}

In the age of social media, the boundaries between online and offline have become fluid. Offline mobilizations end up in social media and vice versa, online actions turn into offline activities. As people continually switch between virtual and real worlds, it is difficult to recognize what is online and offline, private and public, institutional or non-institutional (Filipek \& Chodak, 2016). Respectively, the mobilization of the "Frankowicze" in Poland may be interpreted as a kind of "connective action", as characterized by Bennett and Segerberg (2012). There is no clear organizational coordination of actions taken in online and offline domains as can be found in "collective actions". Social media is the critical coordinative tool that enables large-scale personal access to ongoing discussions and events. Moreover, holders of Swiss franc debts may not be interested in building collective identity because they are "networked individuals" (Rainie \& Wellman, 2012) who are not embedded in groups, and who are pursuing their individually defined goals. Networked individuals are capable of acting jointly, however they come apart with the same speed as they connect. In order to describe the emerging forms of contemporary mobilization, Milan (2015) proposes the term "cloud protesting". She succinctly explains that "the cloud gives voice and visibility to personalized yet universal narratives, connecting individual stories into a broader context that gives them meaning". Connected through universal narratives, "Frankowicze" are a good example of a virtual community, characterized by Rheingold (1993, p. 5) as "social aggregations that emerge from the Net when enough people carry on those public discussions long enough, with sufficient human feeling to form webs of personal relationships in cyberspace". It is therefore expected that activity of "Frankowicze" on Facebook and Twitter is a loosely organized connective action rather than a collective spurt. Through instantaneous sharing, following of and commenting on current news, social media may produce a collective sense of experiencing, while having no identifiable social traits that indicate the existence of community (Humphreys, 2016).

There is a potential danger that knowledge about the emotional mechanisms that drive users' activity on social media may be used for less ethical purposes. It is economically tempting, although morally unacceptable, for 
"owners" of social media sites to manipulate emotions in order to increase online traffic and users' engagement on sites (Kramer, Guillory \& Hancock, 2014). To complicate the matter further, some scholars (Fuchs, 2015; Meikle, 2016; van Dijck, 2013) suggest that owners of social media sites shape online practices of users and then commodify them into saleable products (e.g. data products). There are many ways to influence users' practices on Facebook and Twitter. Algorithms, bots, manipulated content (fake news), functionalities (affordances), etc. may produce or modify practices of people engaged in online interactions with peers. Thus, for political and commercial reasons, content produced by "Frankowicze" may be significantly manipulated by actors using fake accounts or those having backstage "persona". For example, politicians may use social media to promote laws to limit actions of commercial banks involved in Swiss franc borrowing. Even if politicians' proposals appear sometimes far-fetched or naive, they hope to find potential voters among users interested in radical political actions. At the same time, commercial banks may use "information gatherers", "trolls", "sock puppets", or "bots" (Humphreys, 2016, p. 178-79) to influence discussions that are focused on issues that may be important for them (Gorwa, 2017). It would therefore be barely surprising that different categories of actors may try to influence discussions focused on Swiss franc loans. Consequently, it is hypothesized here that institutionally affiliated actors are characterized by different topical structures than those users without institutional affiliation. Different topical structures may suggest such influence; however, based on our data, it is rather impossible to prove that institutional actors manipulate the public sphere on Facebook and Twitter in order to achieve their goals.

It is further assumed that Swiss franc debt holders try to accomplish their individually-defined goals though the universal narratives they develop on social media. Thus, actions taken online could be explained by the "uses and gratification theory", initially proposed by Blumler (1979). In accordance with this powerful theoretical frame, it is alleged that people get active on Facebook and Twitter on purpose and that they do that because they expect to receive some reward or gratification. Consequently, "Frankowicze" engage in online communication to accomplish certain goals, conscious or unconscious, individual or/and collective. However, rational use with the intention to receive some reward or gratification is only part of the story behind online activity. It is worth noting that social media has addictive potential and users are often not able to control their online activity (Berger, J., \& Milkman, 2010: Kuss \& Griffiths, 2011; Ryan, Chester, Reece, \& Xenos, 2014). Still, similarities of individually perceived harm and common narratives that arise from the financial problems caused by Swiss franc loans may bring non-institutionally affiliated users together. It is expected, therefore, that "Frankowicze" who have no institutional affiliation discuss similar 
problems on Facebook and Twitter, as they experience similar problems and cope with similar obstacles. As a consequence, it is hypothesized here that the topical structures of institutionally non-affiliated actors on both platforms are similar, as "Frankowicze" may be driven by the same set of goals, motives, threats, and opportunities related to Swiss franc loans.

\section{Data and method}

\section{Data}

In order to examine activity of Swiss franc mortgage holders in Poland, we used textual data delivered by an external partner (Brand24.pl, a social media data provider operating in Poland) from Facebook and Twitter, gathered between December 2008 and March 2017. Only posts with the following hashtags have been included in our study: \#frankowicze, \#kredytfrankowy, \#bankowebezprawie, \#CHF, \#bankokracja, \#banksterzy, \#kredyty. In total, 17,859 publicly avalaible posts from Facebook $(5,264)$ and Twitter $(12,595)$ were analysed after data cleansing aimed at excluding: (i) posts and tweets with only hashtags and no other textual content, (ii) posts and tweets with relevant hashtags but irrelevant content, e.g. hidden marketing messages or ordinary advertisements. Further, we narrowed our focused to Facebook and Twitter, as they appeared to be the main discussion forums for users holding mortgages in Swiss francs (van der Graaf, Otjes, \& Rasmussen, 2016). Some users were active on both selected social networking sites with similar content produced on each of them.

The Polish language is rather complex due to its gender system, having seven cases, and inflection and conjugation. However, those limitations have been overcome by the usage of "PoliMorfologik" dictionary (Weiss, 2005), which allows the identification of cores of the words used in the studied textual content. Yet, "PoliMorfologik" did not return all cores of the words properly, and some additional programming to correct mistakes was necessary to make this dictionary work more precisely. Textual data was further parsed, cleaned, and processed in Java7 library jsoup 1.10.2.

\section{Method}

Drawing on the research methods and techniques for natural language processing and text mining (Sokolova et al., 2016), including detection or classification of emotions (Balabantaray, Mohammad, \& Sharma, 2012; Ferrara \& Yang, 2015; Gruzd, 2013; Lin \& Utz, 2015) and reconstruction of social networks (Graells-Garrido, Lalmas, \& Baeza-Yates, 2015; Himelboim, Smith, Rainie, Shneiderman, \& Espina, 2017), we proposed a multi-step analytical framework 
aimed at examining our textual data. Initially, we built a dictionary of reference words present in online discussions focused on Swiss franc loans. Our dictionary included words and terms commonly used by "Frankowicze" that could be matched to the different problems that emerged in public debate (see: Appendix $1)$.

In the following step, our reference dictionary was tested on a sample of 59 websites in order to check its efficiency and accuracy (see: Appendix 2). The tests brought promising results; however, we removed several keywords, as they did not match real data from websites. Then, the improved dictionary was applied to the sample of 2,000 posts and tweets randomly selected from the total sample of 17,859 textual units. This trial brought no errors; therefore, we decided to apply our dictionary to the complete dataset.

The next step was aimed at selecting and reducing the amount of data for qualitative analysis. We narrowed the scope of the research to the most active actors participating in discussions on Facebook and Twitter. Accordingly, posts and tweets of 100 active users from both channels were further analysed and qualitatively classified. As a result, the dataset was reduced to 2,335 posts from Facebook and 7,671 tweets from Twitter. Such procedure enabled us to investigate, in detail, institutional affiliation of actors active on social media platforms based on their online username characteristics (e.g. "Bank X", "Law firm Y"). Additionally, it simplified the matching of the most frequent tuples to topics and problems raised by Swiss franc mortgage holders in online debates.

The quantitative analysis of the most active actors and the most frequent tuples was completed with qualitative examination of textual content. This procedure was aimed at recognizing potential problems and topics from the most frequent tuples identified in posts and tweets of the most active users. In other words, we examined the textual content produced by institutionally affiliated and noninstitutionally affiliated actors in order to find topical structures on Facebook and Twitter. We believe that the analysis of tuples gives better results than analysis of single terms; however, it needs further qualitative interpretation that allows the selection of pairs signifying clear and distinctive topics and problems. For example, the pair of words "chf" and "credit", which appears most frequently on Twitter (228), cannot be deemed to refer to any specific problem discussed by Swiss franc mortgage holders. In contrast, a pair made of the words "credit" and "so_called" may suggest that "Frankowicze" are rather disappointed and they do not perceive loans in Swiss franc as a standard and fair financial product. Thus, in the first step, the informative value of tuples was validated, while in the second step, tuples were matched with problems referring to Swiss franc loans. For all subsets, only tuples appearing at least 10 times in posts or tweets were further validated and classified. 


\section{Results}

\section{Actors}

There are different categories of actors engaged in online discussions around the Swiss franc problem in Poland. We found politicians, journalists, banks, exchange bureaus, consulting companies, newspapers, and ordinary citizens sharing content with distinguishing hashtags on Facebook and Twitter. A comparison of 100 the most active actors on Facebook and Twitter revealed that only five of them were active on both social networking sites. We were able to identify an institutional affiliation for $70 \%$ of Facebook and 36\% of Twitter's 100 most active users. The heterogeneity of users on both platforms may partly support $\mathrm{H} 1$, which claims that the discussions on the two analysed platforms are loosely organized connective actions rather than a collective and organized effort to influence politicians and banks.

Following the division of actors into affiliated and non-affiliated, we were able to identify topics and problems that were discussed on both social networking sites. Such a division was necessary to find problems that were raised by ordinary Swiss franc mortgage holders and actors with an institutional background. The division revealed some interesting tendencies presented below.

\section{Keywords}

As was expected, the online discussions among users involved in the Swiss franc problem are dominated by financial and economic issues. For example, the most popular word, "loan", was used in diverse contexts on both sites 9,457 times. Similar results were found for other words explicitly related to the Swiss franc problem: "bank" $(6,938)$, "zloty" $(1,076)$ and "finance" $(1,022)$. Surprisingly, the word "franc" appeared only in 975 of textual entities we analysed. Graph 1 presents the ranking of the 50 most popular keywords from our vocabulary. 


\section{Most frequent words}

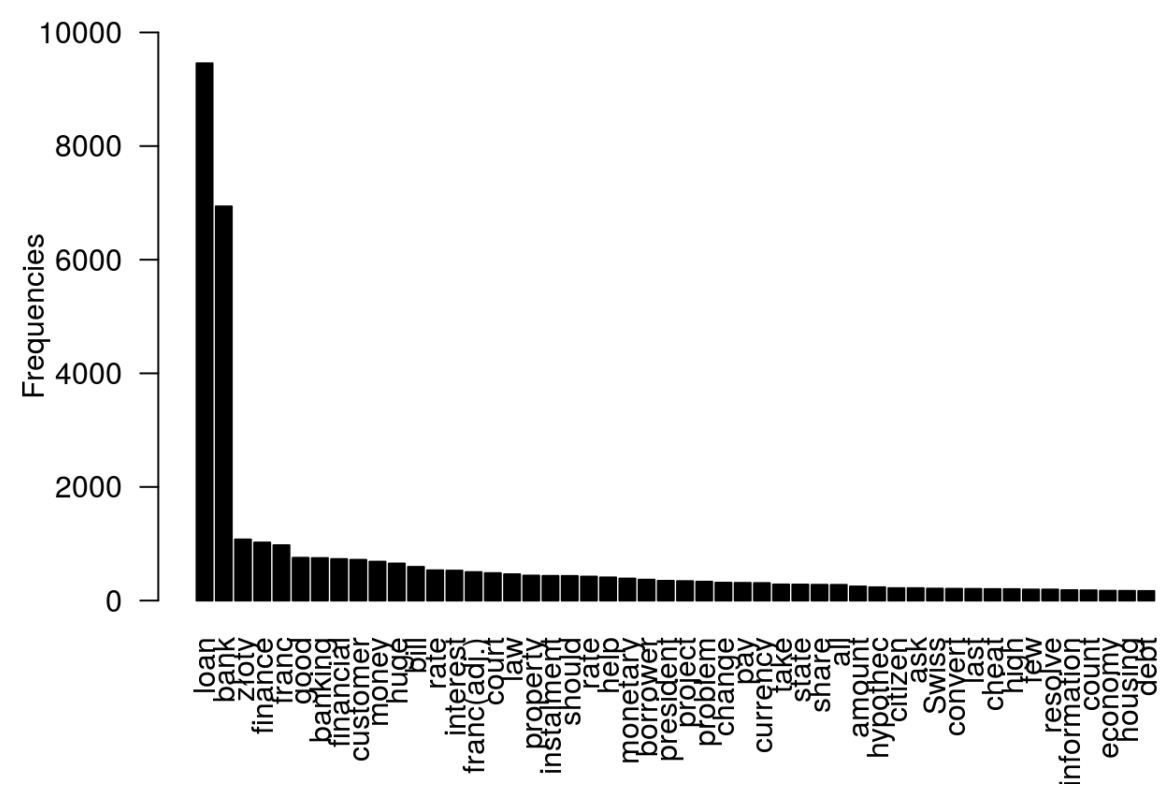

Graph 1. Top 50 words from vocabulary.

\section{Tuples}

As was signalled above, the frequency of single words does not inform much about topics and problems discussed by Swiss franc mortgage holders. However, the tuples identified in the textual data may suggest which problems are discussed online by Swiss franc borrowers. Graphs 2 and 3 show that Facebook and Twitter are two different micro-public spheres with diverse topical structures built around Swiss franc loans. Such a result supports H2, which suggests that Facebook and Twitter are rather dissimilar public spaces with qualitatively different topical structures. Despite its 140 character limit, Twitter appears to be a more vivid space that generates content focused on legal institutions (courts, state, political parties), problems with Swiss franc loans (chf \& pseudocredit $=62$ or chf $\&$ scam $=11$ ), banking law (bill \& project $=36$; Frankowicz \& Pinokiobill $=21$ ), or bank lawlessness (banklawlessness \& usury $=69$ ).

On the other hand, Facebook posts were primarily focused on financial issues such as financial products (mortgage $\&$ credit $=93$; property $\&$ insure $=81$ ), banking solutions (credit $\&$ repay $=27$, credit $\&$ consolidation $=18$, or credit $\&$ conversion $=16)$, or currency $($ rate $\&$ rise $=11$; rate $\&$ fall $=11)$. Thus, Facebook and Twitter have different topical structures, despite the fact we used the same set of hashtags for analysis. More details can be found in Table 2. 
Table 1.

The most frequent tuples

\begin{tabular}{|c|c|c|}
\hline \multicolumn{3}{|c|}{ Twitter } \\
\hline Koyword & Noighboring word & Frequency \\
\hline \multicolumn{3}{|l|}{ agreement } \\
\hline berking & lobby & 23 \\
\hline benking & sector & 10 \\
\hline benking & aากา & 10 \\
\hline berking & slavery & 10 \\
\hline \multicolumn{3}{|l|}{ benklawlessness } \\
\hline \multirow{2}{*}{\multicolumn{3}{|c|}{ benklawlessness }} \\
\hline & remain & 35 \\
\hline \multicolumn{3}{|l|}{ beriklawessness } \\
\hline \multirow{2}{*}{\multicolumn{3}{|c|}{$\begin{array}{l}\text { benklawlessness } \\
\text { henklawWessness }\end{array}$}} \\
\hline & marifestation & 16 \\
\hline \multicolumn{3}{|l|}{ beriklawlessness } \\
\hline \multirow{2}{*}{\multicolumn{3}{|c|}{$\begin{array}{l}\text { benklawlessness } \\
\text { bill }\end{array}$}} \\
\hline & project & 36 \\
\hline \multicolumn{3}{|l|}{ bill } \\
\hline \multicolumn{3}{|c|}{ have (to entitled to) } \\
\hline \multicolumn{3}{|c|}{ credt } \\
\hline \multicolumn{3}{|c|}{ credit } \\
\hline \multicolumn{3}{|c|}{ peeudocredit: } \\
\hline \multicolumn{3}{|c|}{ usury } \\
\hline \multicolumn{3}{|c|}{ toxicbenks } \\
\hline \multicolumn{3}{|c|}{ so called } \\
\hline \multicolumn{3}{|c|}{ seam } \\
\hline \multicolumn{3}{|c|}{ so caled } \\
\hline eredit & benk & 98 \\
\hline credit & consclidation & 48 \\
\hline \multicolumn{3}{|c|}{ agreomen: } \\
\hline \multicolumn{3}{|c|}{ conversion } \\
\hline \multicolumn{3}{|c|}{ Lesury } \\
\hline credit & illogel & 18 \\
\hline credit & toxic & 18 \\
\hline cout & to & 47 \\
\hline court & judgment & 13 \\
\hline franc & scandal & 20 \\
\hline franc & affair & 19 \\
\hline Frarkowicz & Pinckicbill & 21 \\
\hline Frankowicz & affair & 17 \\
\hline Frenkowicz & so caled & 13 \\
\hline Frarkowicz & slsughter & 13 \\
\hline Frarkowicz & help & 13 \\
\hline Frankowicz & no protection & 10 \\
\hline manifestation & & 19 \\
\hline manifestation & bank rules & 17 \\
\hline manifestation & cheat & 17 \\
\hline pis (Law and Just & reredt & 23 \\
\hline pis (Law and Just & rbenk & 23 \\
\hline pis (Law and Just. & ffrarkowicz & 20 \\
\hline state & blind & 12 \\
\hline usury & butable & 13 \\
\hline usury & chif & 12 \\
\hline
\end{tabular}

\begin{tabular}{|c|c|c|}
\hline \multicolumn{3}{|c|}{ Facobook } \\
\hline Keyword & Neighboring word & Frequency \\
\hline agrearrent & trap & 22 \\
\hline banking & $\operatorname{tax}$ & 14 \\
\hline bill & project & 21 \\
\hline credt & грау & 27 \\
\hline credt & help & 19 \\
\hline credit & bubble & 18 \\
\hline credt & consolidation & 16 \\
\hline credit & corwersion (eurrency) & 16 \\
\hline credit & insure & 14 \\
\hline finance & propenty & 78 \\
\hline finance & advise & 36 \\
\hline finance & bil & 24 \\
\hline finanoe & spockesman & 13 \\
\hline mortoge & credit & 93 \\
\hline mortgage & eorsolidation & 21 \\
\hline president & by & 25 \\
\hline property & insure & 81 \\
\hline rate & ise & 11 \\
\hline rate & fall & 11 \\
\hline rise & year & 10 \\
\hline
\end{tabular}

Differences in the problems discussed on the platforms became even more visible when tuples were matched with affiliated and non-affiliated actors who are recognized on both platforms. In both cases, the topical structure differs for institutional and non-institutional actors. In the case of Twitter, non-affiliated actors are a more active online community with unique problems raised in online debates. They most frequently use word clusters (i.e. "banklawlessness") and emphasize the non-legal and non-moral character of loans in Swiss francs. Moreover, the most frequent tuple, "credit" \& "so_called", appeared 119 times. At the same time, institutionally affiliated actors focus primarily on financial products such as mortgage (credit \& mortgage $=27$ ) or home loan (credit \& home $=22$ ). 
However, non-affiliated actors are more active and it is rather obvious that their tweets shape discussions focused on credit in Swiss francs on Twitter. This result does not support $\mathrm{H} 2$.
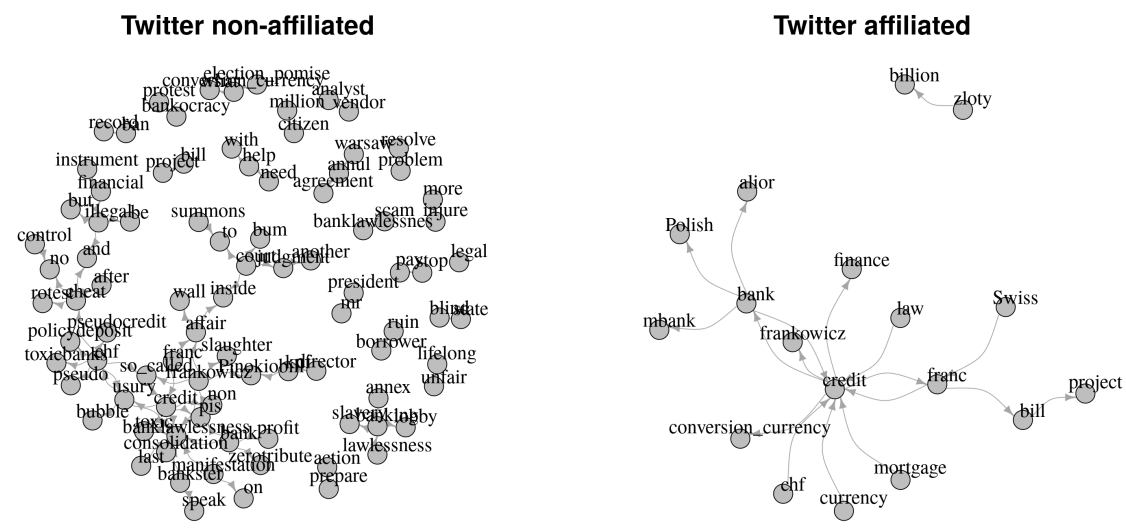

Graph 2. Topical structure for affiliated and non-affiliated actors on Twitter.

Contrary, Facebook actors with institutional affiliation appear to be more active and more engaged in discussions related to Frankowicze issues. Alike Twitter affiliated actors, they focus on financial products (mortgage \& credit $=77$, credit \& finance $=65)$ and rather avoid to discuss negative consequences of bad credits. There are no tuples in their posts with words such as: "usury", "banklawlessness" or "so_called" credit. Surprisingly, non-affiliated actors on Facebook do not raise any specific problems related to Swiss franc credits either. A suggestive pair made of the words "agreement" \& "trap" appeared only 22 times. The most frequent (53) tuple identified in posts of non-institutional actors on Facebook is "property" \& "insure" (Table 2). Thus, in comparison with Twitter's non-affiliated actors, Facebook users are rather weak and non-engaged participants in online discussions focused on Swiss franc loans. H3 is not confirmed, as the topical structures of non-affiliated on Facebook and Twitter are clearly different. 

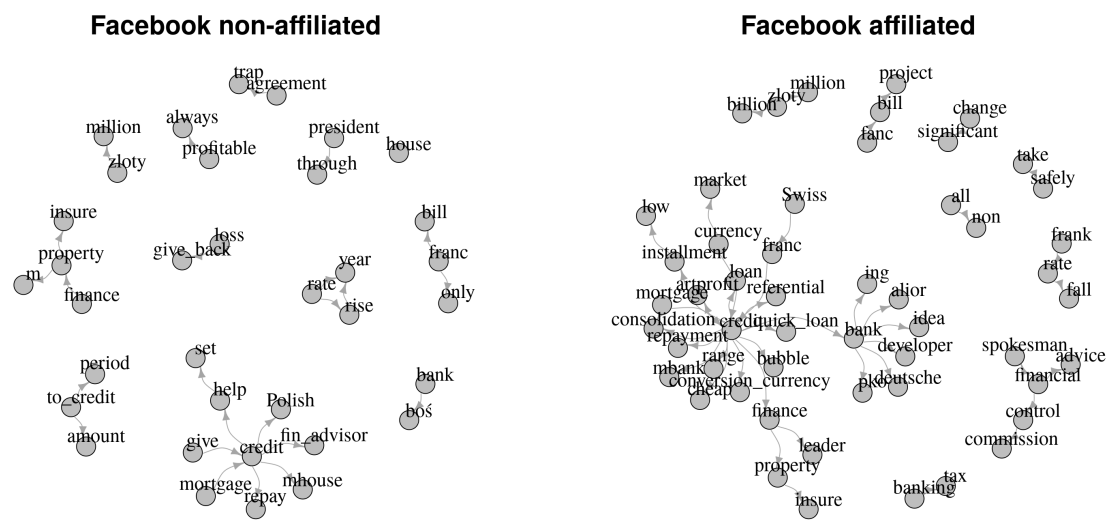

Graph 3. Topical structure for affiliated and non-affiliated actors on Facebook.

\section{Discussion}

The analysis of topics discussed by actors engaged in online discussions around Swiss franc loans highlights some interesting features of the public spheres emerging on Facebook and Twitter. Swiss franc mortgage holders in Poland choose social media to share problems, concerns, and views they have on diverse issues related to credits and borrowing in general. Although the range of problems is wide, which may hamper the emergence of collective identity (Bennett \& Segerberg, 2012), social media give people the feeling of being in a group as part of an online gathering formed by like-minded individuals. Humphreys (2016, pp. 170172) suggests that social media platforms have the potential to build virtual communities with consciousness of a kind (mutual recognition), shared rituals and traditions, and moral responsibility. Yet, "Frankowicze" are relatively young, unshaped, and a vague collectivity, with most of these features at an immature stage. At this early stage of coalescence, the qualitative analysis of keywords and tuples did not deliver solid evidence that could falsify the hypothesis of the connective logic behind online activity of Swiss franc mortgage holders in Poland. But this immaturity may not be unintentional, as there are different categories of actors engaged in online debates with "Frankowicze".

On the other hand, it was found that "Frankowicze" sometimes use Twitter to share information in order to mobilize for protests or demonstrations (53 tuples with keyword "manifestation"). Surprisingly, Facebook was less exploited as a communication space by Swiss franc mortgage holders in Poland. This may suggest that the public sphere on social media is not just a "fictional osmosis" 
(Mohammed, 2012) attracting "slacktivists" (Morozov, 2009) engaged in meaningless clicking or sharing. Spread of information through social media may encourage isolated individuals to take part in collective actions (both online and offline) that are aimed at pursuing specific goals. Thus, despite the immature nature of the virtual community formed by "Frankowicze", some of their actions to put pressure on banks and government may appear to be successful. However, the current developmental stage of "Frankowicze" - many diverse goals, lack of organizational coordination, no indicators of collective actions - confirms that this is loosely organized connective action rather than a collective spurt.

Our analysis further showed that social media may be a good source of information for those interested in critical public issues. Problems discussed by Swiss franc mortgage holders and other engaged parties appear to be important and could be a valuable source of knowledge for politicians, bankers, and ordinary citizens dealing with these kind of issues. We found that citizens usually struggle with attachment of payments, high exchange rates, or currency changeover related to credit in Swiss francs. They also list the financial abuses related to debt and borrowing. At the same time, many users share information and knowledge, helping to overcome existing troubles and highlighting potential dangers for those indebted in Swiss francs. Thus, the analysis of online textual layer suggest that social media may contribute to building new forms of online social capital defined through resources that could be mobilized through personal networks $(\mathrm{N}$. Lin, 1999, 2001; Lin, Cook, \& Burt, 2001).

Then, the online micro-public sphere that can be built around famed or critical problems attracts different categories of actors who pursue their private goals. Accordingly, Facebook and Twitter discussion spheres drew the attention of journalists, politicians, celebrities, businessmen, and ordinary people who took more or less an active part in online discussions. As it is difficult to recognize the real goals behind online communication of such actors, we only show that the structure of topics among institutional and non-institutional actors significantly differs. This may suggest that some actors use social media to create specific (e.g. fake) narratives around Swiss franc loans. It has been found that online discussions in Poland are affected by fake news and disinformation (Gorwa, 2017); therefore, it is reasonable to suspect that some actors engaged in "Frankowicze" problems lie and manipulate in order to pursue their private goals. However, we did not find evidence of fake news and disinformation in the examined textual entities from Facebook and Twitter. Based on our results, it is therefore naive to claim that institutional actors dictate the course of discussions on social media platforms such as Facebook and Twitter. 
Non-institutional actors discuss different problems on Twitter and Facebook. The topical structures for both platforms significantly differ by size, diversity, and frequency of debated topics. Such results may confirm some earlier findings that suggest that users turn to each of these platforms to fulfil different information needs and goals (Pew Research Center, 2015). Furthermore, Facebook appears to be dominated by institutional actors, while Twitter attracts Frankowicze with no institutional affiliation. It is therefore probable that Facebook and Twitter activate different categories of actors focused on problems with Swiss franc loans in Poland.

\section{Limitations and future research}

This study has a number of limitations and some of them need to be raised in order to make our results more eligible and communicable. Firstly, we did not have the tools to identify fake accounts and bots that could affect the shape of online discussions. This problem is known in the literature (Dickerson, Kagan, \& Subrahmanian, 2014; Stringhini, Kruegel, \& Vigna, 2010), and some solutions have been proposed, but they are still imperfect and may cause additional problems when analysing textual data from Facebook and Twitter. However, future studies with established tools for recognizing fake accounts and bots could definitely bring more robust results and could also contribute to understanding the contemporary mechanisms shaping online public spheres.

Another limitation of our study is the database of textual entities, which was provided by external partner. Our analysis was narrowed to Facebook and Twitter due to fact that other channels such blogs or discussion forums are not as rich in textual content focused on credits in Swiss francs. As a consequence, the topical structures of online discussions around Swiss franc loans proposed in our study may be biased by sample constraint. Accordingly, there is room for future research focusing on the online communication channels omitted in our research project, such as blogs and local social networking sites (e.g. NK).

Finally, the method we used to recognize problems and topics from textual data could have a different sequence or design, depending on the data structure or problem analysed. Based on prior experience of scholars analysing textual data (DiMaggio, Nag, \& Blei, 2013; Daoud \& Kohl, 2016) we tried to combine quantitative and qualitative methods in order to build the most comprehensive picture of "Frankowicze" online activity. Yet, short online textual units, such as posts or tweets, may be a poor source of information about users' practices, goals, attitudes etc. On the other hand, character limits (e.g. Twitter) requires users to be concise and straightforward when discussing issues online. Therefore, we believe that the combination of quantitative and qualitative methods allows the uncovering of more than a simple application of one type of research technique. 


\section{Funding}

This study was financed by Polish Ministry of Science and Higher Education grant implemented on the basis of Contract no. 0057/DLG/2016/10 under the program 'Dialogue' (within project entitled 'Debt Watch').

Support for this research was provided by the National Science Centre (NCN), Poland, through Grant No. 2014/12/S/HS6/00390.

\section{Bibliography}

An, J., Quercia, D., \& Crowcroft, J. (2014). Partisan sharing. In Proceedings of the second edition of the ACM conference on Online social networks - COSN'14 (pp. 13-24). ACM Press. http://doi.org/10.1145/2660460.2660469

Balabantaray, R. G., Mohammad, M., \& Sharma, N. (2012). Multi-class Twitter emotion classification: A new approach. International fournal of Applied Information Systems, 4(1), 48-53.

Batorski, D., \& Grzywińska, I. (2017). Three dimensions of the public sphere on Facebook. Information, Communication E Society, 4462(February), 1-19. http://doi.org/ 10.1080/1369118X.2017.1281329

Benkler, Y. (2004). Sharing nicely: On shareable goods and the emergence of sharing as a modality of economic production. The Yale Law fournal, 114(2), 273-358.

Bennett, W. L., \& Segerberg, A. (2012). The logic of connective action. Information, Communication E̊ Society, 15(5), 739-768. http://doi.org/10.1080/1369118X.2012.670661

Berger, J., \& Milkman, K. L. (2012). What makes online content viral? fournal of Marketing Research, 49(2), 192-205. http://doi.org/10.1509/jmr.10.0353

Blumler, J. G. (1979). The Role of Theory in Uses and Gratifications Studies. Communication Research, 6(1), 9-36. http://doi.org/10.1177/009365027900600102

Boulianne, S. (2015). Social media use and participation: A meta-analysis of current research. Information, Communication \& Society, (March), 37-41. http://doi.org/ 10.1080/1369118X.2015.1008542

Boyd, D. (2010). Social network sites as networked publics: Affordances, dynamics, and implications. In Z. Papacharissi (Ed.), Networked self: Identity, community, and culture on social network sites (pp. 39-58). http://doi.org/10.1162/dmal.9780262524834.119

Bureau of Credit Information - Poland. (2017). The picture of sector - January 2017. Extracted from: https://media.bik.pl/informacje-prasowe/att/1090989

CBOS. (2017). Media online. 53/2017. http://www.cbos.pl/SPISKOM.POL/2017/ K_053_17.PDF

Centrum Grabskiego. (2016). Raport 'Kredyty frankowe. Strony sporu i ich argumenty'. http://centrumgrabskiego.pl/wp-content/uploads/2013/10/Raport-Kredytyfrankowe-Strony-sporu-i-ich-argumenty.pdf

Daoud, A., \& Kohl, S. (2016). How much do sociologists write about economic topics? Using big data to test some conventional views in economic sociology, 1890 to 2014 (No. 16/7). MPIfG Discussion Paper. 
Dickerson, J. P., Kagan, V., \& Subrahmanian, V. S. (2014). Using sentiment to detect bots on Twitter: Are humans more opinionated than bots? In IEEE/ACM International Conference on Advances in Social Networks Analysis and Mining (pp. 620-627).

Digrazia, J., Mckelvey, K., Bollen, J., \& Rojas, F. (2013). More Tweets, more votes: Social media as a quantitative indicator of political behavior, $8(11), 1-5$. http://doi.org/ 10.1371/journal.pone.0079449

DiMaggio, P., Nag, M., \& Blei, D. (2013). Exploiting affinities between topic modeling and the sociological perspective on culture: Application to newspaper coverage of U.S. government arts funding. Poetics, 41(6), 570-606. http://doi.org/10.1016/j.poetic.2013.08.004

Ferrara, E. (2015). Manipulation and abuse on social media. ACM SIGWEB Newsletter, (Spring) (4). https://doi.org/10.1145/2749279.2749283

Ferrara, E., \& Yang. Z. (2015). Measuring emotional contagion in social media. PLoS ONE, 11(10), 1-10. http://doi.org/10.1371/journal.pone.0142390

Filipek, K., \& Chodak, J. (2016). Introduction: Rediscovering society in the age of social media. Konteksty Spoteczne/Social Contexts, Special Issue: Rediscovering Society in the Age of Social Media, 4(1), 5-11.

Fuchs, C. (2013). Twitter and democracy: A new public sphere? In Social Media: A Critical Introduction (pp. 179-209). Sage.

Fuchs, C. (2014). Social media and the public sphere. tripleC, 12(1), 57-101.

Fuchs, C. (2015). Culture and economy in the age of social media. Routledge.

Gorwa, R. (2017). Computational propaganda in Poland: False amplifiers and the digital public sphere. In S. Wooley \& P. N. Howard (Eds.), Working Paper 2017.2 (pp. 1-37). Oxford, UK. http://comprop.oii.ox.ac.uk/

Graells-Garrido, E., Lalmas, M., \& Baeza-Yates, R. (2015). Finding intermediary topics between people of opposing views: A case study. arXiv Preprint arXiv:1506.00963. http://arxiv.org/abs/1506.00963

Gruzd, A. (2013). Emotions in the Twitterverse and implications for user interface design. AIS Transactions on Human-Computer Interaction, 5(1), 42-56.

Habermas, J. (1991). The structural transformation of the public sphere (1968 First). MIT Press.

Himelboim, I., Smith, M. A., Rainie, L., Shneiderman, B., \& Espina, C. (2017). Classifying Twitter topic-networks using social network analysis. Social Media + Society, 113. http://doi.org/10.1177/2056305117691545

Humphreys, A. (2016). Social media. Enduring principle. Oxford \& New York: Oxford University Press.

Kramer, A. D. I., Guillory, J. E., \& Hancock, J. T. (2014). Editorial expression of concern: Experimental evidence of massive scale emotional contagion through social networks. Proceedings of the National Academy of Sciences, 111(29), 8788-8790. http:/ /doi.org/10.1073/pnas.1412469111 
Kuss, D. J., \& Griffiths, M. D. (2011). Online social networking and addiction-A review of the psychological literature. International fournal of Environmental Research and Public Health, 8(9), 3528-3552. http://doi.org/10.3390/ijerph8093528

Lewis, S. C. (2015). Reciprocity as a key concept for social media and society. Social Media + Society, 1(1). http://doi.org/10.1080/1

Lin, N. (1999). Building a network theory of social capital. Connections, 22(1), 28-51. http:/ /doi.org/10.1108/14691930410550381

Lin, N. (2001). Social capital. A theory of social structure and action. University Press. http:/ /doi.org/10.1007/s13398-014-0173-7.2

Lin, N., Cook, K., \& Burt, R. (2001). Social capital. theory and research. Aldine de Gruyter.

Lin, R., \& Utz, S. (2015). The emotional responses of browsing Facebook: Happiness, envy, and the role of tie strength. Computers in Human Behavior, 52, 29-38. http:/ /doi.org/10.1016/j.chb.2015.04.064

Lindgren, S., \& Cocq, C. (2017). Turning the inside out: Social media and the broadcasting of indigenous discourse. European Fournal of Communication, 32(2), 131-150. http://doi.org/10.1177/0267323116674112

Meikle, G. (2016). Social media. Communication, sharing and visibility. Routledge.

Milan, S. (2015). From social movements to cloud protesting: The evolution of collective identity. Information, Communication \& Society, 18(8), 887-900. http://doi.org/ 10.1080/1369118X.2015.1043135

Miłkowski, M., \& Weiss, D. (2016). PoliMorfologik. https://github.com/morfologik/polimorfologik.

Mohammed, S. N. (2012). The (dis)information age. The persistence of ignorance. Peter Lanf Publishing.

Morozov, E. (2009). Brave new world of slacktivism. Foreign Policy, (19.05). http://foreignpolicy.com/2009/05/19/the-brave-new-world-of-slacktivism/

Pew Research Center. (2015). The evolving role of news on Twitter and Facebook. http:/ /www.journalism.org/2015/07/14/the-evolving-role-of-news-on-twitter-andfacebook/

Pew Research Center. (2016). The modern news consumer. http://wrww.journalism.org/ 2016/07/07/the-modern-news-consumer/

Radio Poland. (2012). To koniec kredytów we frankach (This is the end of Swiss-franc loans). http:/ /www.polskieradio.pl/42/259/Artykul/570277_

Rainie, L., \& Wellman, B. (2012). Networked: The new social operating system. The MIT Press.

Rheingold, H. (1993). The virtual community. Homesteading on the electronic frontier. AddisonWesley.

Ryan, T., Chester, A., Reece, J., \& Xenos, S. (2014). The uses and abuses of Facebook: A review of Facebook addiction. Fournal of Behavioural Addictions, 3(3), 133-148. http:/ /doi.org/10.1556/JBA.3.2014.016 
Sokolova, M., Huang, K., Matwin, S., Ramisch, J., Sazonova, V., Black, R., Orwa, Ch., Ochieng, S., Sambuli, N. (2016). Topic modelling and event identification from Twitter textual data, 17. http://arxiv.org/abs/1608.02519

Stringhini, G., Kruegel, C., \& Vigna, G. (2010). Detecting spammers on social networks. In The 26th annual computer security applications conference. ACM (pp. 1-9). http:/ /doi.org/10.18535/ijecs/v6i2.14

Sunstein, C. R. (2007). Republic.com 2.0. Princeton University Press.

Tang, G., \& Lee, F. L. F. (2013). Facebook use and political participation: The impact of exposure to shared political information, connections with public political actors, and network structural heterogeneity. Social Science Computer Review, 31(6), 763-773. http://doi.org/10.1177/0894439313490625

van der Graaf, A., Otjes, S., \& Rasmussen, A. (2016). Weapon of the weak? The social media landscape of interest groups. European fournal of Communication, 31(2), 120135. http://doi.org/10.1177/0267323115612210

van Dijck, J. (2013). The culture of connectivity. A critical history of social media. Oxford University Press. http://doi.org/10.1017/CBO9781107415324.004

Vitak, J., Zube, P., Smock, A., Carr, C. T., Ellison, N., \& Lampe, C. (2011). It's complicated: Facebook users' political participation in the 2008 election, 14(3). http:/ /doi.org/10.1089/cyber.2009.0226

We Are Social, \& Hootsuite. (2017). Digital in 2017: Global overview. https://wearesocial.com/uk/blog/2017/01/digital-in-2017-global-overview

Weiss, D. (2005). A survey of freely available Polish stemmers and evaluation of their applicability in information retrieval. 2nd Language and Technology Conference, Poznan, Poland, pp. 216-221. http://morfologik.blogspot.com/ 